\title{
Root-shoot growth and time to transplant of different lettuce (Lactuca sativa $L$.), genotypes during nursery
}

\section{Relación raíces/parte aérea y momento de trasplante para diferentes genotipos de lechuga (Lactuca sativa L.), durante la etapa de propagación}

Carnelos Danilo ${ }^{1}$, Lozano Miglioli Jorge ${ }^{2}$, Fujinuma Pablo ${ }^{1}$, Giardina Ernesto ${ }^{1}$, Di Benedetto Adalberto ${ }^{1,3}$

Originales: Recepción: 12/07/2020 - Aceptación: 19/02/2021

\begin{abstract}
Although vegetable nursery growers decide on plug sizes based on the types, production time and schedule of the crops to grow, they usually choose individual small cell sizes because these allow short plant-raising periods and reduced costs. However, larger plugs produce a finished plant after transplant in a shorter period of time than smaller plugs. Nursery growers end the propagation period when roots take up the plug cell and plantlets can be removed from the plug tray without damage. Thus, this study aimed to investigate the effect of three plug-cell sizes and a single BAP application $\left(100 \mathrm{mg} \mathrm{L}^{-1}\right)$ on the shoot and root growth and time to transplant of different lettuce genotypes. Nursery decreased as plug cell volume increased and with the single BAP spray. A novelty result was that the transplant dates were assigned when the marginal root dry weight accumulation decreased, i.e., based on objective rather than on subjective observations. The significant leaf area and dry weight accumulation found could be explained by growth parameters such as the rate of leaf appearance, the relative rate of leaf area expansion, the relative growth rate, the net assimilation rate and the partition coefficient from root: shoot allometries.
\end{abstract}

\section{Keywords}

synthetic cytokinin - photo-assimilate partitioning • plug tray • root restriction • vegetables

1 Universidad de Buenos Aires. Facultad de Agronomía. Av. San Martín 4453 (C1417DSE). Buenos Aires. Argentina. dibenede@agro.uba.ar

2 Comité de Investigaciones Científicas de la Provincia de Buenos Aires (C.I.C.). Calle 526 entre 10 y 11 (1900). La Plata. Provincia de Buenos Aires. Argentina.

3 Universidad Nacional de Mar del Plata. Facultad de Ciencias Agrarias. Ruta 226. B7620ZAA. Balcarce. Provincia de Buenos Aires. Argentina. 


\section{RESUMEN}

Los propagadores hortícolas deciden el tamaño de la celda basados en la especie y la dinámica de crecimiento, de esta manera eligen los tamaños más pequeños bajo el supuesto de disminuir el período de terminación del esqueje y reducir los costos de producción. Los propagadores sugieren trasplantar cuando las raíces ocupan toda la celda y las plántulas pueden ser extraídas de la celda sin daños visibles; cuanto mayor es el tamaño de la celda, el tiempo hasta trasplante disminuye. El objetivo de este estudio ha sido investigar el efecto de tres tamaños de celda y el asperjado con BAP (100 mg L-1) sobre la acumulación de biomasa aérea y radical y el momento de trasplante para diferentes genotipos de lechuga. Nuestros resultados muestran que el ciclo de propagación disminuyó a medida que se incrementó el volumen de la celda y en las plántulas asperjadas con BAP. El resultado novedoso de este trabajo es que el momento de trasplante fue determinado objetivamente cuando la acumulación marginal de peso seco radical comenzaba a disminuir. Los cambios en la expansión de área foliar y acumulación de peso seco pudieron ser explicados a partir del uso de diferentes estimadores del crecimiento.

\section{Palabras clave}

Citocininas • partición de foto asimilados • tamaño de celda • restricción radical • hortalizas

\section{INTRODUCTION}

In recent years, plant growers have adopted the plug system for seedling propagation based on the assumption that this system may allow minimizing labor costs, increasing crop uniformity, and reducing cropping duration. Plug production is characterized by the use of specialized plug trays, in which the higher the number of cells per tray, the smaller the cells. Although decisions on plug sizes are based on the type, production time and schedule of the crops to grow, vegetable plug growers have mainly adopted containers of reduced size based on the hypothesis that these can increase nursery yield. This choice allows increasing plant density, but has the disadvantage that it restricts root growth, followed by considerable changes in plant growth and physiology (1). In addition, although seedling trays with individual small cell sizes allow short plant-raising periods and reduced costs, larger plugs produce a finished pot plant after transplant in a shorter period of time than smaller plugs (3).

Nursery root restriction would lead to a decrease in both root growth and cytokinin synthesis or translocation. When the container base impedes vertical root growth, the availability of cytokinin synthesized in the root apex and reallocated to shoots would be reduced (12). In this context, data from our laboratory have shown that the exogenous application of the cytokinin 6-benzylaminopurine (BAP) at the pre-transplant stage to plants grown in small cell volumes may override the shoot growth limitation due to root restriction and that the plant response to BAP is related to both the dose and application time (13). Although information on the effect of physical root restriction as a result of a limited plug cell volume on plant growth is available (12), the physiology of the roots growing under impeded plug cell tray conditions during nursery is still vaguely understood.

Based on the above, the aim of this work was to study the growth pattern during nursery of four genotypes of lettuce (Lactuca sativa L.), the most commonly consumed fresh leafy vegetable and one of the main crops grown under greenhouse conditions (22), in the presence of different degrees of root restriction by the use of different plug cell volumes and a single BAP spray as an attempt to explain the potentially different plantlet sizes at the transplant stage. The hypothesis tested indicate that a single BAP application can override plug cell restriction through an increase in leaf area, shoot biomass accumulation and photo-assimilate partitioning to shoots. 


\section{Materials AND Methods}

The experiment was carried out in a greenhouse at the Facultad de Agronomía de la

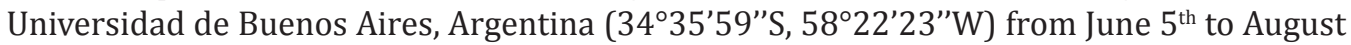
$28^{\text {th }} 2018$ (experiment 1 ) and repeated four times: i) between July $3^{\text {rd }}$ and September $25^{\text {th }}$ 2018 (experiment 2), ii) between August $7^{\text {th }}$ and October $9^{\text {th }} 2018$ (experiment 3), iii) between October $2^{\text {nd }}$ and December $3^{\text {rd }} 2018$ (experiment 4), iv) and between November $8^{\text {th }}$ and December $23^{\text {rd }} 2018$ (experiment 5).

Four lettuce seed genotypes 'Lores' (Vilmorin, France), 'Sandrine' (Clause-Tézier, Spain), 'Taina' (Cohorsil, Honduras) and 'Luana' (Sakata, Japan)] were germinated and grown in 50-, 128- and 288-plug cell plastic trays (55.70, 17.37 and $6.18 \mathrm{~cm}^{3}$ cell $^{-1}$ respectively) filled with Klasmann $411 \AA$ medium (Canadian Sphagnum peat moss-perlite-vermiculite $70 / 20 / 10 \mathrm{v} / \mathrm{v} / \mathrm{v}$ ). Seedlings were sprayed with BAP (SIGMA EC 214-927-5) (Sigma-Aldrich Co., St. Louis, MO, USA) with two treatments, C: control: $0 \mathrm{mg} \mathrm{L}^{-1}$ and BAP: $100 \mathrm{mg} \mathrm{L}^{-1}$ when the first pair of true leaves developed. BAP was previously diluted in alcohol $80 \%$. In this way, 24 combinations were generated that made up 24 experimental units.

Plants were irrigated with high-quality tap water (pH: 6.64 and electrical conductivity of $0.486 \mathrm{dS} \mathrm{m}^{-1}$ ) by using intermittent overhead mist and weekly fertigation (1N:0.5P:1 K:0.5Ca $\mathrm{v} / \mathrm{v} / \mathrm{v} / \mathrm{v}$ ) (Stage 2: $50 \mathrm{mg} \mathrm{L}^{-1} \mathrm{~N}$; Stages 3-4: $100 \mathrm{mg} \mathrm{L}^{-1} \mathrm{~N}$ ). The volume per pot varied according to the container's volume.

Half hourly averages of the air temperature were measured using a HOBO H08-001-02 data logger (Onset Computer Corporation, MA, USA) protected from direct radiation by aluminum foil shades. Global solar radiation was recorded with an additional PAR HOBO data logger. The mean air temperature during the experiment was $19.5 \pm 2.0^{\circ} \mathrm{C}$, while the mean photosynthetic active radiation ranged between 17.33 and 21.81 mol photons $\mathrm{m}^{-2}$ day $^{-1}$.

Plants for destructive measurements (10 per treatment and block) were harvested at emergence and at 7-day intervals. Roots were washed fresh weights (FW) were recorded. Dry weights (DW) were obtained after drying to constant weight at $80^{\circ} \mathrm{C}$ for 96 hours, root, stem and leaf dry weights (DW) were recorded. The number of leaves was recorded as well and each leaf area was determined using the ImageJ® (Image Processing and Analysis in Java) software. We assumed that plants reached the transplant stage when the marginal root DW through time decreased.

The rate of leaf appearance (RLA), the relative growth rate (RGR), the rate of leaf area expansion (RLAE), the mean net assimilation rate (NAR) and the allometric coefficients between roots and shoots were calculated according to Di Benedetto and Tognetti (2016).

Since there were no significant differences between the experiments, data shown are limited to those of experiment 3 , which was conducted in a time of the year in which the four lettuce genotypes are usually propagated.

The experimental design was a randomized design in three blocks of 10 observations of each combination of levels of the evaluated effects (plug cell volume $\times$ BAP application $\times$ lettuce genotype). Data were subjected to analysis of variance (ANOVA). The STATISTICA 8 (StatSoft) software was used and the assumptions of ANOVA were checked. Least significant differences (LSD) values were calculated. Means were separated by Tukey's tests (P $\leq 0.05)$. Slopes from straight-line regressions of RLA, RLAE, RGR, NAR and allometric values were tested using the SMATR package.

\section{RESULTS}

In control plants, nursery cultivation, estimated through the time between seed germination and the transplant stage, was directly related to the plug cell volume: as the plug cell volume increased, the nursery period of all the lettuce genotypes tested decreased. The nursery period was also decreased by the BAP spray at the pre-transplant stage (figure 1, page 92). 
Data are the mean of the five experiments performed $(n=15)$. The vertical line indicates least significant

differences (LSD).

Los datos son promedio de las cinco repeticiones del experimento ( $n=15)$. Las líneas verticales indican la mínima diferencia significativa (MDF).

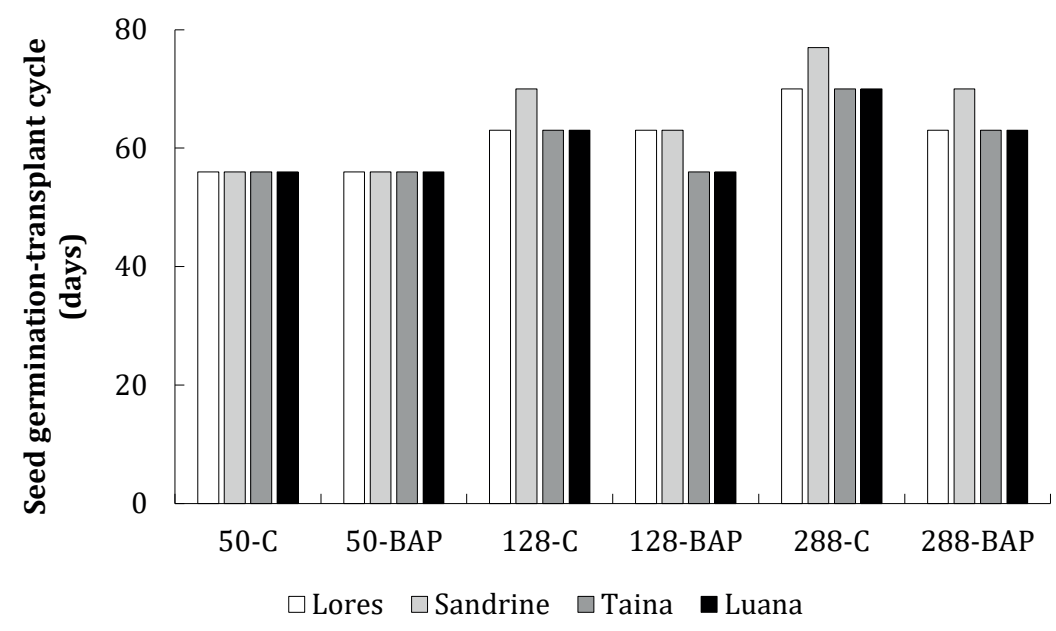

Figure 1. Effects of three plug cell volume (50-, 128- and 288-cell trays $\left.{ }^{-1}\right)$ and a pretransplant BAP spray ( $100 \mathrm{mg} \mathrm{L}^{-1}$ ) (C: control plants) at the time from seed germination and transplant stage of four lettuce genotypes.

Figura 1. Efecto de tres tamaños de celda (50-, 128- y 288-celdas bandeja-1) y el asperjado con BAP en pre-trasplante (C, control: $0 \mathrm{mg} \mathrm{L}^{-1}$ y BAP: $100 \mathrm{mg} \mathrm{L}^{-1}$ ) sobre el ciclo de propagación para cuatro genotipos de lechuga.

At the end of experiment, total leaf areas and shoot FW were highest in control plants grown in 50-plug cell trays and decreased as the plug cell volume decreased. The single BAP spray decreased leaf areas but increased shoot FW in all plug cell volumes tested. The lettuce genotypes showed only quantitative differences to this general response pattern (table 1, page 93).

During the experiment, all lettuce genotypes showed higher RLA in 50-plug cell trays than in smaller plug cell volumes. The single BAP spray always increased RLA values respect to the controls. However, only minor differences in RLAE between treatments were found and no effect of BAP was observed (table 1, page 93).

RGR, which was determined as an estimator of DW accumulation, showed quantitative differences between lettuce genotypes, but, in most plants, the highest RGR values were found in plants grown in 50-plug cell trays and BAP-sprayed plants. We also observed significant differences in NAR, which supports the results observed in lettuce plants from the highest plug cell volumes and BAP-sprayed ones. When RGR was disaggregated into shoots (data not shown) and roots, the RGR of the latter $\left(\mathrm{RGR}_{\mathrm{Roots}}\right)$ was highest in the plants grown in the largest plug cell volume. When the plants were sprayed with BAP, some lettuce genotypes showed a tendency towards a decreased root DW accumulation (table 1, page 93).

The increased $\beta$ coefficients observed in the root-shoot allometries showed a higher photo-assimilate partition to roots as the plug cell volume decreased. In contrast, the BAP spray increased photo-assimilate partition to shoots (decreased $\beta$ coefficients) (table 1, page 93).

\section{DISCUSSION}

To investigate the impact of plug size on below-ground (root growth and resource capture) and above-ground (shoot weight, leaf area) traits, different combinations of shoot and root growth were created using plug cells of different sizes and a single BAP application (100 $\mathrm{mg} \mathrm{L}^{-1}$ ).

Time to transplant is usually a trait with no objective protocols; nursery growers define the end of the propagation period when roots take up the plug cell and plantlets can be removed from the plug tray without damage (6). However, the novelty of the results shown in figure 1 is that they were obtained from data collected when marginal root DW through time decreased (data not shown). 
Table 1. Effects of three plug cell volume (50-, 128- and 288-cell trays ${ }^{-1}$ ) and a pre-transplant BAP spray (100 $\left.\mathrm{mg} \mathrm{L}^{-1}\right)$ on the growth parameters of four lettuce genotypes.

Tabla 1. Efecto de tres tamaños de celda (50-, 128- y 288-celdas bandeja ${ }^{-1}$ ) y el asperjado con BAP en pre-trasplante (100 $\left.\mathrm{mg} \mathrm{L}^{-1}\right)$ sobre los estimadores de crecimiento para cuatro genotipos de lechuga.

\begin{tabular}{|c|c|c|c|c|c|c|c|c|}
\hline & $\begin{array}{c}\text { Leaf area } \\
\left(\mathrm{cm}^{2}\right. \\
\left.\text { plant }^{-1}\right)\end{array}$ & $\begin{array}{l}\text { Shoot FW } \\
\text { (g plant }^{-1} \text { ) }\end{array}$ & $\begin{array}{c}\text { RLA } \\
\text { (leaves } \\
\text { day }^{-1} \text { ) }\end{array}$ & $\begin{array}{c}\text { RLAE } \\
\left(\mathrm{cm}^{2} \mathbf{c m}^{-2}\right. \\
\left.\text { day }^{-1}\right)\end{array}$ & $\begin{array}{c}\text { RGR } \\
\left(\mathrm{g} \mathrm{g}^{-1} \text { day }^{-1}\right)\end{array}$ & $\begin{array}{c}\text { NAR } \\
\left(\mathrm{g} \mathrm{cm}^{-2}\right. \\
\left.\text { day }^{-1}\right) \\
\left.\times 10^{-5}\right)\end{array}$ & $\begin{array}{c}\text { RGR } \\
\left(\mathrm{g} \mathrm{g}^{-1} \text { day }^{-1}\right)\end{array}$ & $\begin{array}{c}\beta \\
\text { coefficient }\end{array}$ \\
\hline $\begin{array}{l}\text { Lores } \\
50-C \\
50-B A P \\
128-C \\
128-B A P \\
288-C \\
288-B A P \\
\end{array}$ & $\begin{array}{r}181.01 \mathrm{aC} \\
149.47 \mathrm{bB} \\
101.98 \mathrm{cB} \\
71.40 \mathrm{~dB} \\
23.96 \mathrm{eB} \\
22.94 \mathrm{eA} \\
\end{array}$ & $\begin{array}{c}4.202 \mathrm{bC} \\
4.815 \mathrm{aC} \\
2.769 \mathrm{dA} \\
3.063 \mathrm{cA} \\
0.613 \mathrm{fC} \\
0.869 \mathrm{eB}\end{array}$ & $\begin{array}{l}0.200 \mathrm{bB} \\
0.218 \mathrm{aB} \\
0.141 \mathrm{~dB} \\
0.182 \mathrm{cB} \\
0.130 \mathrm{eB} \\
0.148 \mathrm{~dB}\end{array}$ & $\begin{array}{l}0.075 \mathrm{aA} \\
0.072 \mathrm{aA} \\
0.062 \mathrm{bA} \\
0.065 \mathrm{bA} \\
0.040 \mathrm{cA} \\
0.038 \mathrm{cA}\end{array}$ & $\begin{array}{l}0.113 \mathrm{aA} \\
0.118 \mathrm{aA} \\
0.097 \mathrm{bA} \\
0.100 \mathrm{bA} \\
0.065 \mathrm{~dB} \\
0.079 \mathrm{cA}\end{array}$ & $\begin{array}{l}257.34 \mathrm{bB} \\
295.63 \mathrm{aD} \\
163.12 \mathrm{eB} \\
216.98 \mathrm{cB} \\
173.90 \mathrm{eA} \\
203.61 \mathrm{dA}\end{array}$ & $\begin{array}{l}0.114 \mathrm{aA} \\
0.108 \mathrm{bA} \\
0.093 \mathrm{cA} \\
0.092 \mathrm{cA} \\
0.072 \mathrm{dA} \\
0.071 \mathrm{dA}\end{array}$ & $\begin{array}{l}1.054 \mathrm{dC} \\
0.905 \mathrm{eB} \\
1.121 \mathrm{bC} \\
1.047 \mathrm{dA} \\
1.673 \mathrm{aB} \\
1.093 \mathrm{cB}\end{array}$ \\
\hline $\begin{array}{l}\text { Sandrine } \\
50-C \\
50-B A P \\
128-C \\
128-B A P \\
288-C \\
288-B A P \\
\end{array}$ & $\begin{array}{r}214.92 \mathrm{aA} \\
115.80 \mathrm{bC} \\
108.60 \mathrm{bB} \\
68.79 \mathrm{cB} \\
30.58 \mathrm{dA} \\
23.71 \mathrm{dA} \\
\end{array}$ & $\begin{array}{l}5.462 \mathrm{bB} \\
5.753 \mathrm{aB} \\
2.364 \mathrm{dD} \\
2.877 \mathrm{cB} \\
0.737 \mathrm{fA} \\
1.014 \mathrm{eA}\end{array}$ & $\begin{array}{l}0.229 \mathrm{bA} \\
0.257 \mathrm{aA} \\
0.163 \mathrm{dA} \\
0.195 \mathrm{cA} \\
0.152 \mathrm{eA} \\
0.164 \mathrm{dA}\end{array}$ & $\begin{array}{l}0.079 \mathrm{aA} \\
0.071 \mathrm{bA} \\
0.066 \mathrm{cA} \\
0.062 \mathrm{cA} \\
0.045 \mathrm{dA} \\
0.040 \mathrm{dA}\end{array}$ & $\begin{array}{l}0.104 \mathrm{bB} \\
0.112 \mathrm{aA} \\
0.098 \mathrm{cA} \\
0.099 \mathrm{cA} \\
0.075 \mathrm{dA} \\
0.078 \mathrm{dA}\end{array}$ & $\begin{array}{l}242.21 \mathrm{cC} \\
342.00 \mathrm{aB} \\
223.48 \mathrm{dA} \\
328.42 \mathrm{bA} \\
181.29 \mathrm{fA} \\
206.85 \mathrm{eA}\end{array}$ & $\begin{array}{l}0.100 \mathrm{bB} \\
0.110 \mathrm{aA} \\
0.082 \mathrm{cB} \\
0.087 \mathrm{cA} \\
0.074 \mathrm{dA} \\
0.070 \mathrm{dA}\end{array}$ & $\begin{array}{l}1.173 \mathrm{cB} \\
0.975 \mathrm{fA} \\
1.277 \mathrm{bB} \\
1.049 \mathrm{eA} \\
1.337 \mathrm{aC} \\
1.088 \mathrm{~dB} \\
\end{array}$ \\
\hline $\begin{array}{l}\text { Taina } \\
50-C \\
50-B A P \\
128-C \\
128-B A P \\
288-C \\
288-B A P\end{array}$ & $\begin{array}{r}200.50 \mathrm{aB} \\
172.41 \mathrm{bA} \\
96.78 \mathrm{cC} \\
77.63 \mathrm{dA} \\
20.65 \mathrm{eB} \\
16.85 \mathrm{eB}\end{array}$ & $\begin{array}{l}5.778 \mathrm{bA} \\
5.974 \mathrm{aA} \\
2.704 \mathrm{dA} \\
2.740 \mathrm{cC} \\
0.590 \mathrm{fD} \\
0.636 \mathrm{eD}\end{array}$ & $\begin{array}{l}0.121 b D \\
0.139 a D \\
0.104 c C \\
0.127 b C \\
0.086 d D \\
0.102 c D\end{array}$ & $\begin{array}{l}0.074 \mathrm{aA} \\
0.073 \mathrm{aA} \\
0.063 \mathrm{bA} \\
0.059 \mathrm{bA} \\
0.041 \mathrm{cA} \\
0.037 \mathrm{cA}\end{array}$ & $\begin{array}{l}0.101 \mathrm{bB} \\
0.112 \mathrm{aA} \\
0.090 \mathrm{cA} \\
0.096 \mathrm{bA} \\
0.056 \mathrm{~dB} \\
0.062 \mathrm{eA}\end{array}$ & $\begin{array}{l}262.43 \mathrm{bB} \\
316.40 \mathrm{aC} \\
175.11 \mathrm{~dB} \\
215.53 \mathrm{cC} \\
120.60 \mathrm{eC} \\
214.91 \mathrm{cA}\end{array}$ & $\begin{array}{l}0.096 \mathrm{bB} \\
0.113 \mathrm{aA} \\
0.079 \mathrm{~dB} \\
0.088 \mathrm{cA} \\
0.071 \mathrm{~dB} \\
0.054 \mathrm{eA}\end{array}$ & $\begin{array}{l}1.253 \mathrm{bA} \\
0.817 \mathrm{dC} \\
1.265 \mathrm{bB} \\
0.822 \mathrm{~dB} \\
1.346 \mathrm{aC} \\
1.209 \mathrm{cA}\end{array}$ \\
\hline $\begin{array}{l}\text { Luana } \\
50-C \\
50-B A P \\
128-C \\
128-B A P \\
288-C \\
288-B A P\end{array}$ & $\begin{array}{r}216.86 \mathrm{aA} \\
99.81 \mathrm{bD} \\
84.99 \mathrm{cD} \\
78.83 \mathrm{dA} \\
24.02 \mathrm{eB} \\
20.14 \mathrm{eA}\end{array}$ & $\begin{array}{l}4.190 \mathrm{bC} \\
4.486 \mathrm{aD} \\
2.523 \mathrm{dC} \\
2.725 \mathrm{cC} \\
0.684 \mathrm{fB} \\
0.760 \mathrm{eC}\end{array}$ & $\begin{array}{l}0.139 \mathrm{bC} \\
0.155 \mathrm{aC} \\
0.113 \mathrm{dC} \\
0.127 \mathrm{cC} \\
0.104 \mathrm{eC} \\
0.114 \mathrm{dC}\end{array}$ & $\begin{array}{l}0.077 \mathrm{aA} \\
0.066 \mathrm{bB} \\
0.061 \mathrm{bA} \\
0.061 \mathrm{bA} \\
0.040 \mathrm{cA} \\
0.038 \mathrm{dA}\end{array}$ & $\begin{array}{l}0.101 \mathrm{aB} \\
0.104 \mathrm{aA} \\
0.102 \mathrm{aA} \\
0.104 \mathrm{aA} \\
0.062 \mathrm{bB} \\
0.063 \mathrm{bA}\end{array}$ & $\begin{array}{c}346.26 \mathrm{bA} \\
400.05 \mathrm{aA} \\
176.23 \mathrm{~dB} \\
220.02 \mathrm{cB} \\
160.45 \mathrm{eB} \\
174.15 \mathrm{~dB}\end{array}$ & $\begin{array}{l}0.105 \mathrm{bB} \\
0.118 \mathrm{aA} \\
0.090 \mathrm{cA} \\
0.097 \mathrm{bA} \\
0.074 \mathrm{dA} \\
0.070 \mathrm{dA}\end{array}$ & $\begin{array}{l}1.251 \mathrm{cA} \\
0.989 \mathrm{eA} \\
1.338 \mathrm{bA} \\
1.045 \mathrm{dA} \\
1.833 \mathrm{aA} \\
1.064 \mathrm{dC}\end{array}$ \\
\hline
\end{tabular}

Different capital letters indicate significant differences $(\mathrm{P}<0.05)$ for the different lettuce genotypes for the same treatment. FW: fresh weight; RLA: rate of leaf appearance; RLAE: relative rate of leaf area expansion; RGR: relative growth rate; NAR: net assimilation rate.

Letras minúsculas diferentes indican diferencias significativas $(\mathrm{P}<0,05)$ entre tratamientos para cada genotipo de lechuga. Letras mayúsculas diferentes indican diferencias significativas $(P<0,05)$ entre genotipos para el mismo tratamiento. FW: peso fresco; RLA: tasa de aparición de hojas; RLAE: tasa relativa of expansión de área foliar; RGR: tasa de crecimiento relativo; NAR: tasa de asimilación neta.

A limited plug cell volume restricts the vertical root growth when the root apical meristem reaches the bottom of the cell or the pot (12). Thus, both primary root growth and root branching decrease and, presumably, the concentration of cytokinin, the main endogenous hormone synthesized by root apical meristems, would decrease as well. At the transplant stage, lettuce plants grown in plug trays may show a well-developed root system with white roots and without damage, but with a root girdling growth around the cell (3). Although a new root system may develop through the lateral roots that arise adventitiously, the effects of the root restriction remain for the following weeks (12). In the present study, as the plug cell volume increased, the time from sowing to transplant decreased. Similarly, the BAP spray decreased the nursery period about two weeks in lettuce plants grown in 128- and 288-plug cell trays and showed no changes in those grown in 50-cell plug cell trays. 
Since we found no significant qualitative differences between experiments, data from table 1 (page 93), which include most growth parameters used to explain the results shown in figure 1 (page 92), are limited to the results of experiment 3 , which was conducted in a period during which the four lettuce genotypes are usually propagated.

Transplant growers need to produce plants that are visually appealing and of acceptable quality for their customers. Aesthetically, the main trait related to plant quality for commercial acceptance of vegetable transplants is total leaf area. Since leaves are the plant organs responsible for light interception, in physiological terms, this implies the need to expand the leaf area at the highest growth rate, which includes both leaf number and individual leaf size. Here, at the transplant stage, plantlets showed higher total leaf area and shoot FW in 50-cell plugs and decreased as the plug cell volume decreased. When plants were sprayed with BAP, seedlings increased their shoot FW related to controls but showed a decreased total leaf area (table 1, page 93). These results are in agreement with previous reports $(4,21)$.

Leaf area development can be characterized by means of two growth parameters: (i) RLA, which is an estimator of leaf initiation and plastochron length, and (ii) RLAE, which allows quantifying leaf expansion. Changes in total leaf area are mainly related to the meristematic shoot apex capacity to initiate and expand leaf primordia. Table 1 (page 93) shows that, in control plants, as the plug cell volume increased, RLA and RLAE increased. The BAP spray increased RLA in higher proportions than RLAE.

Davière and Achard (2017) have shown that the plastochron length of transgenic plants with reduced cytokinin levels may be altered, which explains the ability of a single BAP spray to override root restrictions. Similarly, we have previously shown that the effects of cytokinin on leaf growth rates include both a decrease in the plastochron length and an increase in leaf expansion, accompanied by an increase in the size of the shoot apex meristem through the synthesis of high-molecular weight substances essential for cell growth (9). These two processes are mediated by the down-regulation of the KNOTTED and WUSCHEL genes (18) associated with a high-cytokinin/low-gibberellin ratio.

The primary shoot apical meristem, which is responsible for generating all the aboveground organs, is controlled by hormones, including auxin, cytokinin, and gibberellin, which act both independently and in combination (10). The main function of endogenous cytokinin is to control the cell cycle and shoot apical meristem growth (2). An increase in RLA would indicate a shorter plastochron, which would in turn require an increase in the shoot apical meristem and non-limiting photo-assimilate supply to hold vegetative plant growth. The latter needs an increase in the photosynthetic capacity and/or a change in photo-assimilate partitioning. The higher total leaf area observed in control than in BAP-sprayed plants would be explained by a limited photo-assimilate availability required to expand the high leaf number previously initiated.

Transplants grown in large plug-cell trays are usually taller and have greater leaf areas and shoot-root DW than those grown in small plug-cell trays. Data from control plants are in agreement with this general view. However, BAP-sprayed plants, which had higher final yield (table 1, page 93), showed lower leaf areas as a result of a higher leaf number but lower individual leaf area (data not shown), which forces us to change the concept of transplant quality. Although the leaf area determines the plant capacity of light interception, the relative growth rate (RGR) may vary mainly as a result of the 'physiological component' NAR (net assimilation rate). Our results showed that the higher plug cell volume, the higher the RGR and NAR of control plants. On the other hand, cytokinin are also known to enhance carbon fixations per unit leaf area. The exogenous application of cytokinin has been shown to stimulate the transcription of a wide number of chloroplast genes, which code for the large subunit of Rubisco (24). In previous studies, we also found that direct addition of cytokinin increases leaf thickness (11), and that this may further enhance carbon assimilation per unit leaf area. At the early stages of leaf development, treatment with exogenous BAP accelerates the division of mesophyll cells, whereas at the later stages of development, BAP treatment activates the expansion of growing cells and of those that have just accomplished their growth (17). The results here found in BAP-sprayed plants are in agreement with these previous reports (table 1, page 93). 
Poorter et al. (2012) pointed out that the reduced growth in small pots is caused mainly by a reduction in photosynthesis per unit leaf area. In addition, In addition, Li et al. (2016) has been indicated that, in general, NAR is the best general predictor of the variation in RGR, in agreement with previous reports from our laboratory in spinach $(14,15)$ and lettuce (21). Root restrictions often depress the photosynthetic capacity (23).

For optimal development of the plant as a whole, root and shoot biomass have to be balanced. Photo-assimilates from leaves are used for root and stem growth. A plausible control mechanism for organ growth is the regulation of relative allocation of assimilates among the plant organs. Although the interspecific variation between biomass allocations to above-ground versus below-ground organs is broadly coordinated, these relationships can be largely modified by plant phenotypic adjustments to variable environmental conditions. Changes in the allometric slopes reflect variations in carbon partitioning (19), and carbohydrate partitioning between competing sites is fundamental to plant growth, especially because plants are capable of modifying their resource allocation to favor the growth of their growing parts. The $\mathrm{RGR}_{\text {Roots }}$ found in the present study (table 1, page 93) would be a direct response to a limited volume for root growth.

On the other hand, sinkstrength and source activity can be altered by endogenous hormones and environmental factors. Among endogenous hormones, auxin and cytokinin have major roles in source nutrient remobilization and sink development (25). Plant tissues and organs rich in cytokinins are known to attract assimilate translocation and increase the sink capacity of leaves treated with cytokinins such as benzyl adenine. Changes in the allometric slopes ( $\beta$ coefficient) reflect variations in carbon partitioning in response to the interactions between biotic and abiotic environments. In agreement with the results shown in table 1 (page 93), data from our lab in control Impatiens walleriana plants (6) showed a higher photo-assimilate partitioning towards roots as the plug-cell volume or growing medium quality decreased. In that study, we also showed that a single $100 \mathrm{mg} \mathrm{L}^{-1}$ BAP spray increased the photo-assimilate partitioning towards shoots. In addition, when we analyzed the stem-leaves allometries, we found an increase in the partitioning towards leaves in control plants and an increase in the partitioning towards stems in BAP-treated ones. Although the smaller the cell volume, the higher the percentage of dry matter allocated to roots, the increase in photo-assimilate partitioning towards the shoot apical meristem has been associated with a positive feedback during the first 30 days after an exogenous BAP spray (7).

The genotypes evaluated in the present study were two butter heads and two crisp head lettuce genotypes with different environment requirements. The butter head Lores is seeded and grown during spring, summer and autumn, while the butter head Sandrine is suggested for growing during autumn and winter. On the other hand, the crisp head TAINA is particularly suited for warm season production, while the crisp head LUANA is sown during autumn and winter. Our results indicated, with minor quantitative differences, that the four lettuce genotypes evaluated showed the same response pattern to both limited plug cell volumes and BAP application.

\section{Conclusions}

Present results suggest that the growth response of lettuce seedlings during nursery yields can be optimizing with a correct plug cell volume chosen and BAP use as a result of the higher plantlet and the lower growth time related to costs cultivation, which can validate the proposed hypothesis. Time from transplant was achieved when the marginal root DW through time decreased. This novelty approach give a better objective methodology to define time to transplant although this commercial use is now far. On the other hand, our results showed that plug purchasers would be change their visual criteria when they buy BAP-treated lettuce for increased field yields. 


\section{REFERENCES}

1. Balliu, A.; Sallaku, G.; Nasto, T. 2017. Nursery management practices influence the quality of vegetable seedlings. Italus Hortus. 24(3): 39-52. https//doi.org/ 10.26353/j. itahort/2017.3.3952.

2. Brenner, W. G.; Schmülling, T. 2015. Summarizing and exploring data of a decade of cytokininrelated transcriptomics. Frontier in Plant Science. Volume 6: article 29. https//doi. org/10.3389/fpls.2015.00029.

3. Campolongo, L.; Carnelos, D.; Lozano Miglioli, J.; Fuginuma, P.; Giardina, E.; Di Benedetto, A. 2020. Physiological mechanism involved in the response to four lettuce varieties to a pretransplant root restriction and a 6, benzyl amino purine (BAP) spray. Asian Journal of Agricultural and Horticultural Research. 5(4): 27-43. https//doi.org/10.9734/ AJAHR/2020/v5i430059.

4. Coro, M.; Araki, A.; Rattin, J.; Miravé, P.; Di Benedetto, A. 2014. Lettuce and celery responses to both BAP and PBZ related to the plug cell volume. American Journal of Experimental Agriculture. 4(10): 1103-1119.

5. Davière. J.; Achard P. 2017. Organ communication: Cytokinins on the move. Nature Plants. 3: 17116. https//doi.org/10.3389/fpls.2017.00146

6. De Lojo, J.; Gandolfo, E.; Gómez, D.; Feuring, V.; Monti, S.; Giardina, E.; Boschi, C.; Di Benedetto, A. 2017. Root restriction effects on the bedding pot plant Impatiens walleriana. Journal of Experimental Agriculture International. 15(4): 1-16. https//doi.org/10.9734/ JEAI $/ 2017 / 31997$

7. Di Benedetto, A.; Pagani A. 2013. Dry weight accumulation in the Impatiens walleriana pot plant in responses to different pre-transplant plug cell volume. European Journal of Horticultural Science. 78(2): 76-85.

8. Di Benedetto, A.; Tognetti, J. 2016. Técnicas de análisis de crecimiento de plantas: su aplicación a cultivos intensivos. RIA. 42(3): 258-282.

9. Di Benedetto, A.; Galmarini, C.; Tognetti, J. 2013. Changes in leaf size and in the rate of leaf production contribute to cytokinin-mediated growth promotion in Epipremnum aureum L. cuttings. Journal of Horticultural Science and Biotechnology. 88(2): 179-186.

10. Di Benedetto, A.; Galmarini, C.; Tognetti J. 2015. Effects of combined or single exogenous auxin and/or cytokinin applications on growth and leaf area development in Epipremnum aureum. Journal of Horticultural Science and Biotechnology. 90(6): 643-654.

11. Di Benedetto, A.; Galmarini, C.; Tognetti, J. 2018. New insight into how thigmomorphogenesis affects Epipremnum aureum L.: Interactions between vine training system and exogenous auxin and cytokinin action in plant development. Horticultura Brasileira. 36(4):330-340. https//doi.org/10.1590/s0102-053620180308

12. Di Benedetto, A.; Giardina, E.; De Lojo, J.; Gandolfo, E.; Hakim, G. 2020a. Exogenous Benzyl Amino Purine (BAP) Applications for the Ornamental Pot Industry. In: Cytokinins: Biosynthesis and Uses (Ed. Sonja Kortesmäki), Nova Science Publishers, Inc. NY. USA. p. 1-56.

13. Di Benedetto, A.; Rattin, J.; Carnelos, D.; Lozano-Miglioli, J.; Giardina, E.; Araki, A.; Coro, M.; Pico Estrada, O.; Teruel, J.; Di Matteo, J.; Gerasi, J.; Barrera, L.; Alonso, E.; Grigoli, L. 2020b. Technological Uses of Exogenous Cytokinins in Vegetables. In: Cytokinins: Biosynthesis and Uses (Ed. Sonja Kortesmäki), Nova Science Publishers, Inc. NY. USA. p. 107-155.

14. Di Matteo, J.; Rattin, J.; Di Benedetto, A. 2015. Increase of spinach growth through the use of larger plug cell volume and an exogenous BAP spray. American Journal of Experimental Agriculture. 6(6): 372-383. https//doi.org/10.9734/AJEA/2015/14979.

15. Geraci, J.; Di Matteo, J.; Feuring, V.; Giardina, E.; Di Benedetto, A. 2018. Exogenous BAP spray on biomass accumulation in spinach. Journal Experimental Agriculture International. 25(6): 1-17. https//doi.org/10.9734/JEAI/2018/43753.

16. Li, X.; Schmid, B.; Wang, F.; Paine, C.T. 2016. Net assimilation rate determines the growth rates of 14 species of subtropical forest trees. PloS One. 11(3): e0150644. https//doi.org/10.1371/ journal.pone.0150644.

17. Molinari, J.; Pagani, A.; Buyatti, M.; Giardina, E.; Di Benedetto, A. 2020. Effects of exogenous cytokinin application on the nursery of ornamental plants, mainly 'New Guinea' Impatiens (Impatiens hawkeri Bull) and on their pre- and post-transplant biomass accumulation. In: Cytokinins: Biosynthesis and Uses (Ed. Sonja Kortesmäki), Nova Science Publishers, Inc. NY, USA. p. 57-106.

18. Holt, A. L.; Van Haperen, J. M.; Groot, E. P.; Laux, T. 2014. Signaling in shoot and flower meristems of Arabidopsis thaliana. Current Opinion in Plant Biology. 17: 96-102. https//doi. org/10.1016/j.pbi.2013.11.011

19. Peng, Y.; Yang, Y. 2016. Allometric biomass partitioning under nitrogen enrichment: Evidence from manipulative experiments around the world. Science Report. 6: 28918. https//doi. org/10.1038/srep28918

20. Poorter, H.; Niklas, K. J.; Reich, P. B.; Oleksyn, J.; Poot, P.; Mommer, L. 2012. Biomass allocation to leaves, stems and roots: meta-analyses of interspecific variation and environmental control. New Phytologist. 193(1): 30-50. https//doi.org/10.1111/j.1469-8137.2011.03952.x 
21. Salinas, M.; Gandolfo, E.; Hakim, G.; Giardina, E.; Di Benedetto, A. 2019. Foliar amino acids sprays on lettuce (Lactuca sativa L.) biomass accumulation. International Journal of Current Microbiology and Applied Sciences. 8(1): 2183-2196. https//doi.org/10.20546/ ijcmas.2019.801.228

22. Shehata, S. M.; Schmidhalter, U.; Valšíková, M.; Junge, H. 2016. Effect of biostimulants on yield and quality of head lettuce grown under two sources of nitrogen. Gesunde Pflanzen. 68(1): 3339. https//doi.org/10.1007/s10343-016-0357-5

23. Shi, K.; Ding, X. T.; Dong, D. K.; Zhou, Y. H.; Yu, J. Q. 2008. Root restriction-induced limitation to photosynthesis in tomato (Lycopersicon esculentum Mill.) leaves. Scientia Horticulturae. 117(3): 197-202. https//doi.org/10.1016/j.scienta.2008.04.010

24. Wu, X.; Zhu, Z.; Li, X.; Zha, D. 2012. Effects of cytokinin on photosynthetic gas exchange, chlorophyll fluorescence parameters and antioxidative system in seedlings of eggplant (Solanum melongena L.) under salinity stress. Acta Physiologiae Plantarum. 34(6): 2105-2114. https//doi.org/10.1007/s11738-012-1010-2.

25. Yu, S. M.; Lo, S. F.; Ho, T. H. D. 2015. Source-sink communication: regulated by hormone, nutrient, and stress cross-signaling. Trends in Plant Science. 20(12): 844-857. https//doi. org/10.1016/j.tplants.2015.10.009. 